\title{
Jana Szymczyka socjologia ciała i kultury fizycznej
}

$\bigvee_{\text {przedmiotem nauk przyrodniczo-medycznych i humanistycznych, literatu- }}^{\text {spólkonstytutywnym elementem/wymiarem człowieka jest ciało bedace }}$ ry pięknej, sztuki, malarstwa, filozofii, socjologii i teologii. W grecko-rzymskim antyku ludzkie ciało często było ukazywane przez rzeźbiarzy i malarzy, natomiast w pismach ówczesnych filozofów było marginalizowane. Rewaloryzacja ciała człowieka nastąpiła w filozofii nowożytnej i współczesnej, lecz jego ontyczny status oraz rola egzystencjalna i społeczna były rozumiane niejednokrotnie diametralnie odmiennie. Somatyczno-biologiczna sfera człowieka jest rozpatrywana we współczesnej socjologii, której subdyscyplinami są socjologia ciała oraz socjologia kultury fizycznej, obejmująca sport i turystykę.

Socjologia jako autonomiczna dyscyplina naukowa została wyodrębniona z nauk społecznych w pierwszej połowie XIX stulecia. Jeszcze później pojawiły się socjologia ciała i socjologia sportu, które w Polsce są szczególnym przedmiotem zainteresowania profesorów Akademii Wychowania Fizycznego w Warszawie: Zbigniewa Krawczyka, Jerzego Kosiewicza i Zbigniewa Dziubińskiego. Problematyka ciała i kultury fizycznej w ostatnich latach zajmuje znaczące miejsce

* Ks. prof. dr hab. Stanisław Kowalczyk - były kierownik Katedry Filozofii Społecznej na Wydziale Nauk Społecznych Katolickiego Uniwersytetu Lubelskiego. Były Dziekan Wydziału Nauk Społecznych KUL oraz były Rektor WSD w Sandomierzu.

${ }^{1}$ Socjologia kultury fizycznej, red. Z. Dziubiński, Z. Krawczyk, Wydawnictwo AWF, Warszawa 2011, ss. 19-37, 141-162; J. Kosiewicz, Filozoficzne aspekty kultury fizycznej i sportu, Wydawnictwo BK, Warszawa 2004. Prof. Z. Dziubiński jest organizatorem ogólnopolskich konferencji na temat problematyki sportu, których pokłosiem jest seria publikacji wydawanych przez AWF w Warszawie 
w pracach profesora Katolickiego Uniwersytetu Lubelskiego, księdza dra hab. Jana Szymczyka (1963-2020), mojego ucznia, a przed przedwczesną śmiercią Dyrektora Instytutu Nauk Socjologicznych i Kierownika Katedry Socjologii Struktur, Procesów Społecznych i Pracy Socjalnej na Wydziale Nauk Społecznych KUL ${ }^{2}$.

\section{Humanistyczno-aksjologiczny profil socjologii}

Właściwe rozumienie roli ciała wymaga odwołania się do integralnej koncepcji człowieka, również socjologia kultury fizycznej jest powiązana z socjologią ogólną. Piotr Sztompka napisał, że socjologia ,jest to nauka o ludziach działających w polu wzajemnych relacji (w "przestrzeni międzyludzkiej»), którzy nadają temu polu nieustanną dynamikę funkcjonowania i stawania się (podtrzymują «życie społeczne»), a utrwalone często niezamierzone efekty swoich działań pozostawiają jako ramy strukturalne i kulturowe kolejnych działań następujących po sobie pokoleniom"3. J. Szymczyk włączył się aktywnie w dyskusję omawiającą przedmiot, metodologię i profil socjologii. Tematem jego rozprawy habilitacyjnej była naukowa twórczość prof. Stanisława Ossowskiego, który był zwolennikiem socjologii humanistycznej ${ }^{4}$. W pokrewny sposób zinterpretował metodologiczny aspekt socjologii lubelski socjolog, który za integralny przedmiot swych rozważań uznał sferę wartości, inicjując m.in. publikację serii prac Studia nad Wartościami. Perspektywa Socjologii Makrostruktur i Ruchów Społecznych ${ }^{5}$.

Problematyka wartości jest rdzeniem analiz filozoficzno-antropologicznych ${ }^{6}$. Autor pracy Odkrywanie wartości także dostrzegał antropologiczne podstawy aksjologii, pisząc: „Pierwszorzędnym podmiotem, «nosicielem» wartości jest jednostka ludzka. (...) Psycho-społeczna perspektywa jest zatem najbardziej właściwym podejściem do analizy świata wartości” ${ }^{\prime}$. One są istotną częścią

i Salezjańską Organizację Sportową RP. Integralnym elementem tych prac o charakterze monograficznym jest tematyka socjologii sportu.

2 J. Szymczyk, Elements of the Application of the Complementarity Principle. Issues of the Socjology of Subiectivity and Social Structures, Wydawnictwo Adam Marszałek, Torun 2014; tenże, Elementy kultury i sportu z perspektywy aksjologii. W kręgu myśli Stanisława Kowalczyka, „Roczniki Nauk Społecznych" 2012, t. 4, nr 1, s. 81-106.

${ }_{3}^{3}$ P. Sztompka, Socjologia. Analiza społeczeństwa, Znak, Kraków 2002, s. 36.

${ }^{4}$ J. Szymczyk, Elements..., s. 14-20.

${ }_{5}^{5}$ T. 1 serii: Wartości, interesy, struktury społeczne. Uwarunkowania ludzkiej kreatywności i partycypacji $w$ życiu publicznym, Norbertinum, Lublin 2010; t. 2: Segmenty aktywności społecznej a wartości. Idee i praktyka, Wydawnictwo KUL, Lublin 2012.

${ }^{6}$ S. Kowalczyk, Człowiek w poszukiwaniu wartości. Elementy aksjologii personalistycznej, Wydawnictwo KUL Lublin 2011.

${ }^{7}$ J. Szymczyk, Odkrywanie wartości. Z problematyki socjologiczno-aksjologicznej, Polihymnia, Lublin 2004, s. 7. 
świata ludzkiego: indywidualnych osób i struktur społecznych. Z socjologii nie można usunąć problematyki wartości i sądów wartościujących. Psychofizyczna struktura ludzkiej osobowości była niejednokrotnie źródłem „dysonansu aksjologicznego", człowiek bowiem potrzebuje różnych wartości, których preferencja różnicuje się w zależności od sytuacji życiowych, indywidualnych postaw i społecznego kontekstu .

Profesor J. Szymczyk, solidaryzując się z myślą społeczną S. Ossowskiego, świat wartości - zwłaszcza wyższych - łączył z fenomenem kultury. Ona ujawnia i potwierdza nasze człowieczeństwo oraz ponadmaterialną podmiotowość osoby ludzkiej'. Człowiek tworzy kulturę, a ona poprzez życie społeczne na różnych jego poziomach psychicznie go kształtuje. Kulturą jest bogaty i zróżnicowany jakościowo świat wartości. „Sferę wartości należy traktować jako powszechny fenomen świata ludzkiego, nieodłączny od sposobu istnienia człowieka w tej warstwie, którą powszechnie określa się mianem "kultura»"10. Punktem odniesienia wartości jest człowiek jako osoba rozumna, wolna i prospołeczna. Lubelski socjolog wyróżnił dwojakie wartości: jedne dotyczą indywidualnej osoby, a inne mają wymiar społeczny. Wartości osobowe są również zróżnicowane, istnieją bowiem wartości podstawowe, zwane także ostatecznymi, oraz wartości życia codziennego. Są one nieodzowne dla człowieka, lecz wartości ostateczne odgrywają rolę kluczową: wskazują na hierarchię aksjologiczną i nadają sens życiu ludzkiemu ${ }^{11}$.

J. Szymczyk jako socjolog koncentrował uwagę na komunikacyjno-społecznej roli wartości. One także są zróżnicowane jakościowo: te, które są „podstawą organizacji systemu społecznego oraz tożsamości kulturowej”, są wartościami podstawowymi i centralnymi ${ }^{12}$. One współtworzą dobro wspólne społeczności, dlatego wymagają dialogu i konsensusu. Bonum commune jest sumą „wszystkich wartości (dóbr), jak i wszystkich koniecznych do ich realizacji struktur społecznych (instytucji) i sposobów zachowania (cnót), które są warunkiem tego, że społeczeństwo w ogóle może zaistnieć"13. Humanistyczno-aksjologiczna interpretacja idei dobra wspólnego diametralnie różni się od kolektywizmu marksistowsko-komunistycznego $\mathrm{z}$ dwu racji: autentyczne dobro wspólne implikuje prawa i rozwój osoby ludzkiej oraz posiada ono fundament etyczno-moralny ${ }^{14}$. Perspektywizm moralny jest destrukcyjny dla kultury i społecznego

8 Tamże, s. 135-139.

9 Tamże, s. 39 nn.

10 J. Szymczyk, Pomiędzy marzeniami a faktami. Szkice socjologiczne, Norbertinum, Lublin 2005, s. 136.

11 Tamże, s. 135-193.

12 Tamże, s. 137.

13 Tenże, Odkrywanie wartości..., s. 37.

${ }^{14}$ Zob. J. Krucina, Dobro wspólne. Teoria i jej zastosowanie, Wydawnictwo Wrocławskiej Księgarni Archidiecezjalnej, Wrocław 1972; S. Kowalczyk, Człowiek a społeczność. Zarys filozofii społecznej, Wydawnictwo KUL, Lublin 2005, s. 232-241. 
ładu, aksjologiczny relatywizm niszczy relacje i więzi na różnych poziomach życia społecznego ${ }^{15}$. Wartości są podstawą interpersonalnych relacji i dynamizmu społecznego, one decydują o postawach człowieka i trwałości społeczności (lokalnych, etnicznych, polityczno-państwowych).

Współcześnie mówi się o kryzysie wartości, J. Szymczyk korygował taki pogląd: prawdziwe wartości osobowe i społeczne są niezmienne i trwałe, istnieje natomiast kryzys ich realizacji1'. Posiada on różne źródła: dychotomia pomiędzy wartościami deklarowanymi a faktycznie realizowanymi, brak internalizacji aprobowanych wartości społecznego konsensusu, etyczny nihilizm. Aksjologiczny daltonizm w każdej formie prowadzi do kulturowego chaosu w życiu społecznym ${ }^{17}$. Niebezpieczna jest jednak również absolutyzacja jednego typu wartości, np. witalno-hedonistycznych, połączona z marginalizacją czy nawet odrzuceniem innych. Dominująca rola religijnych wartości nie wyklucza tych wszystkich, które są niezbędne dla psychofizycznej osobowości człowieka. Aksjologia J. Szymczyka jest socjologiczną analizą sfery wartości, pośrednio jednak implikuje antropologiczny personalizm filozofii klasyczno-chrześcijańskiej. Humanistyczna socjologia S. Ossowskiego została przez niego włączona w dynamiczno-aksjologiczną koncepcję człowieka i społeczności.

\section{Socjologia ciała}

Ogólna socjologia bada struktury i procesy społeczne w dwu wymiarach: mikro i makro; przedmiotem pierwszej z nich są małe społeczności, np. rodziny i społeczności lokalne, drugiej natomiast społeczności i procesy w dużej skali, np. narody i państwa. Z klasycznej socjologii ogólnej wyodrębniły się socjologie szczegółowe, których zakres badań jest ograniczony do niektórych sektorów życia społecznego, np. socjologia wsi, miast, moralności, kultury, religii itd. Jedną z socjologii szczegółowych jest socjologia ludzkiego ciała, której J. Szymczyk poświęcił wiele uwagi i twórczych przemyśleńn ${ }^{18}$. W swych rozważaniach wykorzystał najnowszą literaturę polską i obcojęzyczną (głównie angielską), dokonując umiejętnej rekapitulacji współczesnej socjologii cielesności, wnosząc do niej własne konstatacje.

Nestor polskiej socjologii kultury fizycznej, prof. Zbigniew Krawczyk, wyróżnił trzy jej modele: historyczny, analityczny i empiryczno-opisowy ${ }^{19}$.

${ }^{15}$ J. Szymczyk, Pomiędzy marzeniami a faktami..., s. 147 nn.; tenże, Odkrywanie wartości..., s. 152 nn.

${ }_{16}$ Tenże, Pomiędzy marzeniami a faktami..., s. 139.

17 Tamże, s. $145 \mathrm{nn}$.

18 Tenże, Elements..., s. 210-239.

19 Z. Krawczyk, Teoretyczne orientacje w socjologii kultury fizycznej, w: Socjologia kultury fizycznej..., s. $41 \mathrm{nn}$. 
Kultura fizyczna, obejmująca głównie sport i turystykę, jest ściśle powiązana z aktywnością somatyczno-ruchową człowieka, dlatego wyróżnione modele można odnieść także do socjologii ciała. Profesor KUL referując problematykę ludzkiej cielesności, nawiązywał głównie do modelu opisowo-empirycznego w klasyfikacji Z. Krawczyka, ale jego rozważania zawierają również znaczące elementy dwu pozostałych modeli. W swej analizie koncentrował się na kilku blokach tematycznych: historii powstania socjologii ciała, bytowym statusie ludzkiego ciała, jego roli w aspekcie indywidualnym i społecznym oraz współczesnych procesach społeczno-kulturowych dotyczących somatycznej sfery człowieka.

Socjologia ciała jest dyscypliną relatywnie nową. J. Szymczyk datuje jej powstanie na lata dziewięćdziesiąte, pełną jej autonomizację po $2000 \mathrm{r}^{20}{ }^{20}$ Różnorodne nurty tej subdyscypliny socjologicznej były powiązane $\mathrm{z}$ socjologią kultury, socjologią medycyny, socjologią kultury fizycznej, fenomenologią i postmodernizmem (Michel Foucault). Teoretyczna i metodologiczna samoświadomość socjologii ciała wypracowana została dość późno, ale klasyczna socjologia ogólna - chociaż nie mówiła zbyt wiele o roli ciała w życiu człowieka to jednak implikowała jego obecność oraz aktywność. Inni autorzy wskazują na bezpośrednie powiązanie socjologii ciała z socjologią sportu, co pozwala mówić o socjologii cielesności już po II wojnie światowej ${ }^{21}$.

Centralnym przedmiotem socjologii ciała $\mathrm{w}$ ujęciu lubelskiego profesora jest socjologiczny opis jego ontycznego statusu. Czym jest ciało człowieka? Podstawowym rozróżnieniem $w$ analizach socjologów jest ujmowanie ciała w dwu wymiarach: naturalno-biologicznym i społeczno-kulturowym ${ }^{22}$. Zwolennicy naturalizmu i biologicznego determinizmu traktują ciało jako obiektywno-uniwersalny fenomen stanowiący tworzywo bytowe człowieka. Socjologia wyróżnia „ciało biologiczne” i „ciało kulturowe”, to ostatnie jest swoistym „produktem społecznym", powiązanym z określoną kulturą. Ciała ludzkie różnią się: wiekiem, stanem zdrowia, wyglądem, płcią, atrakcyjnością itp. Współczesna cywilizacja akcentuje społeczno-kulturową rolę ciał, która podlega szybkim przemianom, medycyna kosmetyczna i medyczna technika dokonują częstych interwencji w konstrukcji elementów ciała i wyglądzie człowieka, lecz ich zakres jest limitowany przez proces starzenia się człowieka i nieuchronność śmierci²3. J. Szymczyk w swej socjologii ciała nie ograniczył się do metody empiryczno-deskrypcyjnej, lecz korzystał również z metody teoretyczno-analitycznej grawitującej niejed-

${ }^{20}$ J. Szymczyk, Elementy socjologii ciała, w: Socjologia medycyny w multidyscyplinarnych badaniach humanizujących biomedycynę, red. M. Skrzypek, Wydawnictwo KUL, Lublin 2013, s. 201-208; tenże, Elements..., s. $221 \mathrm{nn}$.

${ }^{21}$ Zob. A. Wohl, Socjologia kultury fizycznej, t. 1-2, Wydawnictwo AWF, Warszawa 1979-1981.

22 J. Szymczyk, Elementy socjologii ciała..., s. 210-217; tenże, Elements..., s. $210 \mathrm{nn}$.

${ }^{23}$ Tenże, Elements..., s. 213 nn. 
nokrotnie na pograniczu refleksji filozoficznej. Jednocześnie zdystansował się do ekstremalnych ujęć naturalistyczno-biologicznych i konstruktywistyczno-społecznych. „W socjologii ciała - stwierdził - nierzadko przywoływane są koncepcje z zakresu filozofii czy antropologii. Filozofia w pewnym zakresie dostarczyła socjologom kategorii pojęciowych, pozwalających pokazywać złożoność i wieloaspektowość ludzkiej somatyczności”24. Biologiczna sfera człowieka - jego soma jest powiązana ze sferą psychiczno-umysłową - psyche. Lubelski socjolog ciała dystansował się od skrajnego dualizmu antropologicznego Kartezjusza, natomiast afirmująco odwoływał się do Gabriela Marcela, Viktora Frankla i teologii ciała papieża Jana Pawła II ${ }^{25}$. Egtystencjalista G. Marcel akcentował dwojaki wymiar ludzkiego ciała: przedmiotowy („mam ciało") i podmiotowy („,jestem ciałem”). V. Frankl, psycholog i twórca logoterapii, określił człowieka jako całość cielesno-psychiczno-duchową ${ }^{26}$. Jego koncepcja człowieka - osoby wykracza poza granice opisowej psychologii i posiada charakter filozoficznej konstatacji. Teologia ciała Jana Pawła II jest logiczną konsekwencją chrześcijańskiej prawdy o Wcieleniu Chrystusa, którego ciało dowartościowało ludzką somatyczność. Finałem rozważań nad bytowym statusem ludzkiego ciała jest stwierdzenie, że socjologia nie może ignorować faktu, iż człowiek w swym działaniu fizycznym jest podmiotowo-osobowym „ja”, w którym soma i psyche wzajemnie na siebie oddziałują ${ }^{27}$.

Przedmiotem socjologii ciała jest także jego rola w życiu człowieka w dwu wymiarach: indywidualnym i społecznym. Ten problem jest również obszernie analizowany w pracach J. Szymczyka. Naturalno-biologiczne ciało jest dane człowiekowi, stanowiąc jego element tożsamości dzięki złożonej strukturze i niepowtarzalności, a także jest źródłem doświadczenia oraz wiedzy o świecie ${ }^{28}$. „Somatyczna tożsamość” jest wyrazem indywidualno-jednostkowej autoidentyfikacji. „Wizerunek ciała” i fizyczna atrakcyjność człowieka odgrywa ważną rolę w społecznych interrelacjach, ponieważ we współczesnej konsumpcyjnej cywilizacji ciało utraciło charakter prywatny i stało się społecznym produktem ${ }^{29}$. Uczony lubelski wiele uwagi poświęcił społecznej roli ciała, które stanowi medium pomiędzy człowiekiem a sektorami życia społecznego, w tym również politycznego i religijnego. Awerbalna mowa

${ }^{24}$ Tenże, Elementy socjologii ciała..., s. 209.

25 Tenże, Zaufanie a soma. Rola ciała człowieka w interakcjach społecznych, w: Zaufanie społeczne. Teoria - idee - praktyka, red. J. Szymczyk, Oficyna Naukowa, Warszawa 2016, s. 407 nn; 445.

${ }^{26}$ V. Frankl, Homo patiens, tłum. R. Czarnecki, Z.J. Jaroszewski, Wydawnictwo PAX, Warszawa 1984; S. Kowalczyk, Nurty personalizmu Od Augustyna do Wojtyty, Wydawnictwo KUL, Lublin 2010, s. $163-172$.

${ }^{27}$ J. Szymczyk, Elementy socjologii ciała..., s. 212; tenże, Zaufanie a soma..., s. $432 \mathrm{nn}$.

28 Tenże, Elementy socjologii ciała..., s. 220.

29 Tenże, Zaufanie a soma..., s. 415, 431. 
ciała odgrywa istotną rolę w kreowaniu publicznego wizerunku polityków, m.in.: ich mimika, gestykulacja, postawa, sposób witania się, naturalność czy sztuczność („maska”), umiejętność zachowania się w zaskakujących sytuacjach $^{30}$. Mowa ciała jest istotna również w życiu religijnym: modlitwie, liturgii, adoracji Eucharystii, posłudze charytatywnej ${ }^{31}$. Ciało człowieka jest publiczno-kulturowym wyrazem jego osobowej tożsamości, społecznego statusu, przynależności etnicznej, preferencji seksualnej, ideologicznej opcji, osobistych upodobań itp. Komunikacyjno-społeczna rola ciała rzutuje na sposób funkcjonowania $\mathrm{w}$ życiu codziennym ludzi z niepełnosprawościami fizycznymi, którzy wymagają opieki. „Wizerunkowy” profil ciała jest czasem powiązany z zaniżoną samooceną i brakiem akceptacji siebie, co prowadzi do praktyk szkodliwych dla zdrowia, np. anareksji3 ${ }^{32}$.

Socjologia ciała w ujęciu J. Szymczyka uwzględnia współczesne procesy społeczno-kulturowe i ekonomiczno-merkantylne w traktowaniu cielesności człowieka. Socjologia ciała zazębia się z socjologią medycyny, a często wymaga także znajomości prawa, np. w sprawie dokonywania implantów. Inżynieria medyczna, będąca na usługach utylitarno-hedonistycznej kultury somatycznej, domaga się instytucjonalizacji społeczno-prawnej. Społeczno-kulturowe traktowanie roli ciała jest powiązane z upowszechniającą się jego komercjalizacją, której przejawami są: konkursy piękności, patologiczne afiszowanie się nagością, „rzeźbienie” sylwetki ciała, poszukiwanie jego idealnego "modelu”. Ciało ludzkie stało się głównym przedmiotem utylitarnej kultury, sztuki, nauki, literatury pięknej, a niejednokrotnie towarem rynkowym ${ }^{33}$. W wyniku różnorodnych interwencji (działań) sportowo-wyczynowych, kosmetyczno-estetycznych, chirurgicznych, stało się ono „produktem społecznym”, a równocześnie jest wizerunkiem człowieka, jego „wizytówką" i autokreacją.

Prace prof. J. Szymczyka nie tylko prezentują współczesny stan badań z zakresu socjologii ciała, lecz także dokumentują jego osobiste stanowisko w tym zakresie. Dostrzegając psychosomatyczną złożoność człowieka, akcentował komplementarność jego soma i psyche, dowartościował pluralizm roli cielesności i opowiedział się za humanistyczno-aksjologiczną socjologią ciała ${ }^{34}$.

30 Tenże, Funkcje mowy ciała w procesie kreowania wizerunku publicznego polityków, „Roczniki Nauk Społecznych” 2018, t. 10, nr 2, s. 131-161.

31 Tenże, Religijna funkcja mowy ciała, „Civitas Christiana” 2018, nr 8-9, s. 35-36.

32 Tenże, Zaufanie a soma..., s. 439-444; tenże, Dysfunkcjonalna recepcja wizerunku ciała człowieka i jej społeczne skutki, w: Na krawędzi. Reperkusje zachowań ryzykownych w relacji do ciała, red. P. Prüfer, Wydawnictwo Naukowe im. Jakuba z Paraduży, Gorzów Wielkopolski 2016, s. $25-47$.

33 Tenże, Elements..., s, 211 nn.

34 Tenże, Elementy socjologii ciała..., s. 211. 


\section{Socjologia sportu i turystyki}

Zwieńczeniem socjologii ciała J. Szymczyka jest jego socjologia aktywności fizycznej, obejmująca sport i turystykę $e^{35}$. Socjologiczna analiza tych dwu najważniejszych sektorów aktywności somatyczno-ruchowej człowieka wymaga wstępnego wyjaśnienia pokrewnych znaczeniowo pojęć: aktywności fizycznej, kultury fizycznej i sportu. Aktywność fizyczna, nazywana także aktywnością ruchową, obejmuje: „wszelką działalność człowieka związaną z wykonywaniem dowolnego ruchu czy wysiłku ciała, czynności motorycznych"36. Jej celem jest mobilizacja ciała do większej mobilności, wysiłku i nabycia tężyzny. Służą temu: styl życia promujący zdrowie, umiarkowany, ale regularny wysiłek fizyczny poprzez spacery, pływanie jazdę na rowerze czy nartach, gry na świeżym powietrzu itd. Fizyczna aktywność może być powiązana z pracą albo podejmowana dobrowolnie; ta pierwsza to m.in. sport zawodowo-profesjonalny, natomiast druga jest sportem amatorsko-rekreacyjnym. Fizyczną aktywność uprawia ok. $60 \%$ mieszkańców Polski ${ }^{37}$.

Wzajemne relacje pojęć kultury fizycznej i sportu są przedmiotem kontrowersji w literaturze socjologicznej. W krajach anglosaskich są one traktowane zamiennie, natomiast w Europie Środkowo-Wschodniej częściej jest używany termin „sport"38. Problem wymaga precyzji semantycznej, ponieważ pojęcie kultury fizycznej jest konotacyjnie szersze od pojęcia sportu, chociaż jest on jej centralnym sektorem ${ }^{39}$. Do kultury fizycznej należą ćwiczenia somatyczno-rehabilitacyjne, aktywność związana z osobistą higieną, zabiegi kosmetyczne itp.

Kluczową rolę w aktywności fizycznej człowieka odgrywa sport, który jest różnie opisywany. Jedni autorzy eksponują w sporcie aktywność somatyczną człowieka, inni wskazują na ważny współudział sfery psychiczno-umysłowej ${ }^{40}$. J. Szymczyk, podobnie jak Stanisław Kowalczyk, określa sport jako „kreatywną aktywność ruchową człowieka, realizowaną zgodnie z przyjętymi regułami, zawierającą elementy gry (zabawy) i rywalizacji, będącą czasem także pracą (w sporcie profesjonalnym), mającą na celu spotęgowanie somatycznych dosko-

35 Tenże, Elements..., s, 244-264

36 Tenże, Elementy interdyscyplinarnej kooperacji socjologii ciała, sportu i turystyki, w: Podstawy interdyscyplinarności w naukach o zdrowiu. Poznawcza tożsamość dyscyplin badających socjokulturowy wymiar zdrowia i choroby, red. M. Skrzypek, Wydawnictwo KUL, Lublin 2014, s. 117.

37 Tenże, Elements..., s. 245.

38 Tenże, Elementy interdyscyplinarnej kooperacji..., s. $119 \mathrm{nn}$.

39 Zob. Z. Krawczyk, Powstanie i rozwój socjologii kultury fizycznej, w: Socjologia kultury fizycznej..., s. 27 nn.; S. Kowalczyk, Elementy filozofii i teologii sportu, TN KUL, Lublin 2002, s. 24 nn.

40 Zob. J. Kosiewicz, O pojęciu i metodzie kultury fizycznej, w: Sport na przełomie tysiącleci. Szanse i nadzieje, red. Z. Dziubiński, Salezjańska Organizacja Sportowa RP, Warszawa 2000, s. 125 nn. 
nałości i możliwości człowieka oraz wszechstronny rozwój jego osobowości”"11. Cytowany opis sportu wskazuje, że jego konstytutywnymi czynnikami są: rywalizacja mająca na celu zwycięstwo, kreatywność i perfekcjonizm (doskonalenie się w określonej dyscyplinie sportowej).

Socjolog lubelski omawiając aktywność sportową człowieka, podkreślił, że jest ona fenomenem złożonym i wieloaspektowym. W strukturze sportu wyodrębnił następujące elementy: „psychofizyczne (podkreślenie roli ciała, rozumienie sprawności i wydolności fizycznej, ale i uwzględnianie sensu psyche czy nawet integralnego rozwoju osoby); podmiotowo-personalne (zawodnicy, menedżerowie, kibice); ideowo-normatywne (preferowanie wartości, role i normy społeczne, stosunki panujące $\mathrm{w}$ organizacjach i instytucjach sportowych, symbole, ceremonie); materialne (obiekty sportowe, ubiory, firmy sportowe)" Przedstawiona struktura sportu jest kontynuacją ogólnie przyjmowanego stanowiska, że w sporcie są istotne trojakie elementy: podmiotowo-personalne, ideowo-normatywne i materialne. J. Szymczyk w pierwszym elemencie podmiotowo-personalnym rozgraniczył: psychofizyczną aktywność właściwą gatunkowej naturze człowieka oraz działania indywidualno-subiektywne, np. zawodników czy fanów sportowych.

Charakterystycznym rysem sportu jest jego polimorfizm. Pojęcie to jest dwojako rozumiane: może oznaczać pluralizm rodzajów sportu (sport amatorsko-rekreacyjny, zawodowy, rehabilitacyjny, młodzieżowy) bądź wskazywać na ontologiczno-antropologiczne elementy gry sportowej. J. Szymczyk przyjął drugi sens pojęcia polimorfizmu, mówiąc, że do istotnych elementów sportu należą: rywalizacja, możliwość odpoczynku i rekreacji, doświadczenie quasi-świąteczne, parateatr, nawiązywanie relacji interpersonalno-społecznych, gra, zabawa i samorealizacja ${ }^{43}$. Obecnie sport zawodowy stał się intratnym biznesem, co sprzyja jego wynaturzeniom. Socjologia sportu jest powiązana z socjologią ciała, współcześnie ciało sportowca odgrywa także rolę estetyczno-wzorcową i komercyjną. Sport profesjonalny podlega procesom ekonomizacji, komercjalizacji i globalizacji, czego efektem jest często instrumentalne traktowanie zawodników (są oni kupowani i sprzedawani przez kluby sportowe) ${ }^{44}$.

Problematyka sportu jest wieloaspektowa, jej sektorami są: ontologia i antropologia sportu, społeczne aspekty aktywności sportowej, etyczna ocena sportu, jego estetyka i relacja do religii ${ }^{45}$. J. Szymczyk jako socjolog strukturę

${ }^{41}$ J. Szymczyk, Elementy aktywności fizycznej. Socjologia ciała, sportu i turystyki, w: 100 lat socjologii w Katolickim Uniwersytecie Lubelskim. Idee - teorie - badania, red. W. Szymczak, TN KUL, Lublin 2018, s. 377. Zob. S. Kowalczyk, Elementy filozofii i teologii sportu..., s. 31

${ }_{42}$ J. Szymczyk, Elementy aktywności fizycznej..., s. 378.

${ }^{43}$ Tenże, Elementy interdyscyplinarnej kooperacji..., s. 121.

${ }_{44}$ Tenże, Elements..., s. 248.

${ }^{45}$ S. Kowalczyk, Elementy filozofii i teologii sportu..., s. 83-212 
i polimorfizm sportu omawiał w sposób skrótowy, natomiast bardziej obszernie analizował aksjologię sportu. W bogatej palecie wartości związanych z aktywnością sportową wyróżnił następujące: witalne, społeczne, ekonomiczne, etyczne, estetyczne i religijne ${ }^{46}$.

Sport może posiadać charakter autoteliczny, tym niemniej jest on w sposób naturalny powiązany $\mathrm{z}$ wieloma wartościami ważnymi w życiu człowieka i społeczności. Jego pierwszorzędnym celem są wartości witalne; zdrowie (nie tylko somatyczne, lecz także psychiczne i społeczne), witalność, zwinność ciała, tężyzna fizyczna itp. Ludzki organizm ma ograniczenia biologiczne, dlatego nadmierne jego wyeksploatowanie - częste w sporcie zawodowo-wyczynowym jest katastrofalne dla człowieka. Sport uprawiany jest zwykle zespołowo, dlatego dużym jego walorem są wartości prospołeczne w ramach: drużyny sportowej, klubu, społeczności etnicznej (patriotyzm) i globalno-światowej (olimpiady). Integracyjno-społeczna funkcja sportu realizuje się poprzez: relacje interpersonalne, zasady gry, symbole, „kult” sportowych gwiazd (zwłaszcza w środowiskach młodzieży).

Lubelski socjolog eksponował również etyczne wartości gry sportowej, która odpowiedzialnie traktowana wymaga posiadania moralnych cnót: roztropności, sprawiedliwości, uczciwości (zasada fair play), cierpliwości, posłuszeństwa, solidarności wobec zespołu. „Moralnemu aspektowi sportu zagrażają: merkantylizacja, brutalizacja sportu zawodowego, fenomen korporeizmu (kult ciała), sztuczny doping itp." ${ }^{47}$. Sport profesjonalno-zawodowy jest powiązany $\mathrm{z}$ wysokimi zarobkami, które jednak osiągają tylko utalentowani sportowcy. Taki sport podlega zasadom rynku: daje wybitnym zawodnikom kolosalne gratyfikacje, lecz naraża ich na ryzyko utraty zdrowia, a nawet życia. Elementem aksjologii sportu w ujęciu J. Szymczyka są również wartości estetyczne, których uzewnętrznieniem jest ludzkie ciało (jego piękno, płynność dynamiki, tempo gry itp.) oraz dramaturgia zespołowych wydarzeń sportowych. Sport dla jego fanów i obserwatorów jest parateatrem, w którym - w opozycji do prawdziwego teatru - aktywnie współuczestniczą. Widowiskowo-teatralny charakter sportu w sposób szczególny jest widoczny podczas olimpiad. Dyskusyjnym problemem sportu jest jego relacja do religii ${ }^{48}$. Prof. J. Szymczyk jest zdania, że sport nie powinien być traktowany jako parareligia ani nie jest on bezpośrednio powiązany ze sferą wierzeń religijnych (jak było w greckim antyku), natomiast głęboko przeżywana wiara w Boga może pozytywnie inspirować sportowców i wpływać na sposób ich gry. Finalnym elementem socjologicznej analizy

${ }^{46}$ J. Szymczyk, Elementy interdyscyplinarnej kooperacji..., s. 121-125; tenże, Elements..., s. 248-252.

47 Tenże, Elementy interdyscyplinarnej kooperacji..., s. 123. Por. J. Cygan, Personalistyczna etyka sportu, w: Personalistyczna wizja sportu, red. M. Barlak, Wydawnictwo Salezjańskie, Warszawa 1994, s. $42-54$.

${ }^{48}$ Tenże, Elements..., s. 252; tenże, Elementy interdyscyplinarnej kooperacji..., s. 125. 
sportu omawianego autora jest zagadnienie ewentualnego wpływu wydarzeń sportowych na międzynarodowy pokój ${ }^{49}$. Grecy podczas olimpiad zawieszali wszelkie spory i walki, współcześnie olimpiady sportowe nie pełnią jednak roli pokojowej, zarówno w skali globalnej (w czasie II wojny światowej nie organizowano olimpiad), jak i lokalno-etnicznej (w trakcie niektórych olimpiad dochodziło do aktów terroryzmu).

Drugim sektorem kultury fizycznej jest turystyka, której problematyce J. Szymczyk poświęcił także wiele uwagi ${ }^{50}$. Po wstępnych uwagach historycznych i semantycznych, za Krzysztofem Przecławskim, określił turystykę jako formę społecznych relacji polegającą na czasowej zmianie miejsca pobytu i dotychczasowego otoczenia, mającą na celu osobiste doświadczenie nowych wartości związanych z przyrodą, kulturą czy społecznością etniczną.

W naturze człowieka zawarta jest mobilność i chęć podróżowania, dlatego człowiek jest opisywany jako homo viator - pielgrzym ${ }^{51}$. Turystyka zwykle posiada inspirację aksjologiczną, ludzie pragną poznać interesującą przyrodę, zwyczaje obcych ludów oraz różnego typu wartości estetyczne, kulturowe, etniczne, służące zdrowiu itp. Aktywność fizyczno-turystyczna zakłada posiadanie dobrej kondycji witalnej, dotyczy to szczególnie taternictwa, kajakarstwa czy jazdy na nartach w górach, które wymagają specjalistycznego przygotowania. Turystyka jest poszukiwaną formą rekreacji oraz psychofizycznej rehabilitacji. Jest ona również okazją do nawiązywania nowych relacji indywidualnych i społecznych oraz dialogu kulturowego czy religijnego.

J. Szymczyk jako socjolog zwrócił uwagę na ekonomiczny aspekt turystyki, która wymaga: odpowiedniej infrastruktury (hoteli, miejsc rozrywki, środków transportu itd.), organizacji, logistyki, informacji, środków finansowych. Ekonomizacja turystyki jest procesem naturalnym, lecz powoduje ona także negatywne konsekwencje, mianowicie marginalizację aspektów humanistyczno-aksjologicznych w relacjach pomiędzy ludźmi i narodami.

Sport i turystyka w przeszłości były traktowane jako dwie różne formy somatyczno-ruchowej aktywności człowieka, współcześnie granica pomiędzy nimi się zaciera ${ }^{52}$. Można nawet sądzić, że turystyka jest częścią sportu. Turystyka sportowa może być aktywna lub pasywna, obie wymagają zmiany miejsca pobytu, ale różnią się istotnie od siebie. Aktywna turystyka sportowa wymaga dużego wysiłku fizycznego, dobrej kondycji i ma charakter prozdrowotny. Pasywna turystyka sportowa również łączy się z podróżą, np. do miejsc sportowych wy-

49 Zob. J. M. Brohm, Socjologie politique du sport, Jean-Pierre Delarge, Paris 1976.

50 J. Szymczyk, Elementy interdyscyplinarnej kooperacji..., s. 125-135; tenże, Elements..., s. 253-257.

Zob. Z. Łyko, Filozofia rekreacji i turystyki, Signa Temporis, Podkowa Leśna 2004.

${ }^{51}$ G. Marcel, Homo viator. Wstęp do metafizyki nadziei, PAX, Warszawa 1981, s. 158 nn.

52 J. Szymczyk, Elementy interdyscyplinarnej kooperacji..., s. 132-136; tenże, Elementy aktywności fizycznej..., s. 383-386; tenże, Elements..., s. 257-264. 
darzeń, lecz później polega na ich oglądaniu i komentowaniu. Sport i turystyka są ze sobą powiązane społecznie, funkcjonalnie i aksjologicznie, oba sektory fizycznej kultury mają zbieżne cele: kreatywność, zdrowie, przyjaźń, lojalność itp. Można więc mówić o komplementarności sportu i turystyki, dotyczy to również ich funkcji społeczno-politycznych i ekonomicznych ${ }^{53}$. Niektóre formy turystyki są korelatywne do paralelnych typów sportu, charakteryzują je pokrewne cele i wartości. Chociaż współczesny sport często łączy się z turystyką, a ta zawiera zwykle elementy aktywności sportowej, to jednak stanowią one różne formy fizycznej aktywności człowieka ze względu na ich cele pierwszoplanowe i sposób funkcjonowania.

W palecie różnych form fizycznej aktywności człowieka coraz większą popularnością cieszą się ekstremalne rodzaje sportu i turystyki. Sport uprawiany zespołowo jest rywalizacją pojedynczych osób lub sportowych drużyn/zespołów, natomiast sporty ekstremalne w swej istocie są przezwyciężeniem własnych ograniczeń, psychicznej słabości i uzależnień od praw natury. Są inspirowane adrenaliną, stanowiąc ryzyko dla zdrowia, a niejednokrotnie nawet życia ${ }^{54}$.

Socjologia ciała, sportu i turystyki J. Szymczyka jest socjologicznym realistyczno-obiektywnym opisem somatyczno-biologicznej sfery człowieka i jego fizycznej aktywności, ale w pewnych finalnych konstatacjach wykracza poza granice socjologii empiryczno-deskrypcyjnej ${ }^{55}$. Jest to stanowisko zasadne, ponieważ socjologia nie może być zredukowana do obserwacji, a następnie generalizacji fizycznej aktywności ludzkiej osoby w duchu naturalistycznego behawioryzmu i biologicznego redukcjonizmu, które są zafałszowaniem psychicznej natury człowieka poprzez ewidentny antyhumanizm. Sportowiec posiada nie tylko soma, lecz także psyche; jego fizyczna aktywność sportowa i turystyczna są inspirowane przez wiele wartości: witalne, poznawcze, etyczne, społeczne, a często także ideowe. Socjologia cielesności człowieka i jego fizycznej aktywności profesora KUL ma charakter humanistyczno-aksjologiczny. Wieloaspektowość jego socjologicznych i teoretyczno-eksplikacyjnych analiz ujmuje komplementarnie indywidualny i społeczny, obiektywno-zewnętrzny i subiektywno-wewnętrzny wymiar aktywności fizycznej człowieka.

J. Szymczyk włączył się aktywnie i twórczo w polską socjologię w zakresie problematyki ciała człowieka i jego fizycznej aktywności. Nie można jednak także pominąć jego roli jako dydaktyka - był promotorem wielu prac dyplomowych z zakresu socjologii ciała i sportu (niektóre z nich były nagrodzone przez Akademię Wychowania Fizycznego w Warszawie) ${ }^{56}$.

\footnotetext{
53 Tenże, Elements..., s. 262 nn.

54 Tenże, Elementy interdyscyplinarnej kooperacji..., s. $133 \mathrm{nn}$.

55 Tenże, Elements..., s. 265-268 nn.

56 Tenże, Elementy aktywności fizycznej..., s. 374, 380.
} 


\section{Bibliografia}

Brohm M., Sociologie politique du sport, Jean-Pierre Delarge, Paris 1976.

Cygan J., Personalistyczna etyka sportu, w: Personalistyczna wizja sportu, red. M. Barlak, Wydawnictwo Salezjańskie, Warszawa 1994, s. 42-54.

Frankl V., Homo patiens, tłum. R. Czarnecki, Z.J. Jaroszewski, Wydawnictwo PAX, Warszawa 1984.

Kosiewicz J., Filozoficzne aspekty kultury fizycznej i sportu, Wydawnictwo BK, Warszawa 2004.

Kowalczyk S., Człowiek a społeczność. Zarys filozofii społecznej, Wydawnictwo KUL, Lublin 2005.

Kowalczyk S., Człowiek w poszukiwaniu wartości. Elementy aksjologii personalistycznej, Wydawnictwo KUL Lublin 2011.

Kowalczyk S., Elementy filozofii i teologii sportu, TN KUL Lublin 2002.

Kowalczyk S., Nurty personalizmu Od Augustyna do Wojtyły, Wydawnictwo KUL, Lublin 2010.

Krucina J., Dobro wspólne. Teoria i jej zastosowanie, Wydawnictwo Wrocławskiej Księgarni Archidiecezjalnej, Wrocław 1972.

Łyko Z., Filozofia rekreacji i turystyki, Signa Temporis, Podkowa Leśna 2004.

Marcel G., Homo viator. Wstęp do metafizyki nadziei, tłum. P. Lublicz, posł. A. Podsiad, PAX, Warszawa 1981.

Socjologia kultury fizycznej, red. Z. Dziubiński, Z. Krawczyk, Wydawnictwo AWF, Warszawa 2011.

Sztompka P., Socjologia. Analiza społeczeństwa, Znak, Kraków 2002.

Szymczyk J., Dysfunkcjonalna recepcja wizerunku ciała człowieka i jej społeczne skutki, w: Na krawędzi. Reperkusje zachowań ryzykownych w relacji do ciała, red. P. Prüfer, Wydawnictwo Naukowe im. Jakuba z Paraduży, Gorzów Wielkopolski 2016, s. 25-47.

Szymczyk J., Elements of the Application of the Complementarity Principle. Issues of the Sociology of Subjectivity and Social Structures, Wydawnictwo Adam Marszałek, Toruń 2014.

Szymczyk J., Elementy aktywności fizycznej. Socjologia ciała, sportu i turystyki, w: 100 lat socjologii w Katolickim Uniwersytecie Lubelskim. Idee - teorie - badania, red. W. Szymczak, TN KUL, Lublin 2018, s. 373-388.

Szymczyk J., Elementy interdyscyplinarnej kooperacji socjologii ciała, sportu i turystyki, w: Podstawy interdyscyplinarności w naukach o zdrowiu. Poznawcza tożsamość dyscyplin badających socjokulturowy wymiar zdrowia i choroby, red. M. Skrzypek, Wydawnictwo KUL, Lublin 2014, s. 113-136.

Szymczyk J., Elementy kultury i sportu z perspektywy aksjologii. W kręgu myśli Stanisława Kowalczyka, „Roczniki Nauk Społecznych” 2012, t. 4, nr 1, s. 81-106.

Szymczyk J., Elementy socjologii ciała, w: Socjologia medycyny w multidyscyplinarnych badaniach humanizujących biomedycynę, red. M. Skrzypek, Wydawnictwo KUL, Lublin 2013, s. 197-222.

Szymczyk J., Funkcje mowy ciała w procesie kreowania wizerunku publicznego polityków, ,Roczniki Nauk Społecznych" 2018, t. 10, nr 2, s. 131-161.

Szymczyk J., Odkrywanie wartości. Z problematyki socjologiczno-aksjologicznej, Polihymnia, Lublin 2004.

Szymczyk J., Pomiędzy marzeniami a faktami. Szkice socjologiczne, Norbertinum, Lublin 2005.

Szymczyk J., Religijna funkcja mowy ciała, "Civitas Christiana” 2018, nr 8-9, s. 35-36.

Szymczyk J., Wartości, interesy, struktury społeczne. Uwarunkowania ludzkiej kreatywności i partycypacji w życiu publicznym, Studia nad Wartościami. Perspektywa Socjologii Makrostruktur i Ruchów Społecznych, t. 1, Norbertinum, Lublin 2010.

Szymczyk J., Segmenty aktywności społecznej a wartości. Idee i praktyka, Studia nad Wartościami. Perspektywa Socjologii Makrostruktur i Ruchów Społecznych, t. 2, Wydawnictwo KUL, Lublin 2012.

Szymczyk J., Zaufanie a soma. Rola ciała człowieka w interakcjach społecznych, w: Zaufanie społeczne. Teoria - idee - praktyka, red. J. Szymczyk, Oficyna Naukowa, Warszawa 2016.

Wohl A., Socjologia kultury fizycznej, t. 1-2, Wydawnictwo AWF, Warszawa 1979-1981. 


\section{Streszczenie}

Artykuł został podzielony na trzy części. W pierwszej omówiono humanistyczno-aksjologiczny profil socjologii w ujęciu J. Szymczyka. Zgodnie z nim wartości są ściśle powiązane z osobą ludzką: podstawowe wartości zyskują sens w odniesieniu do ludzkiego życia i tworzą dobro wspólne społeczeństwa, a zatem relatywizm moralny jest destruktywny dla kultury i porządku społecznego. Druga część artykuły przedstawiono znaczenie ciała ludzkiego, jego konsekwencje dla ludzkiego życia indywidualnego i społecznego, przekształceń społeczno-kulturowych i ekonomicznych powiązanych z pojmowaniem cielesności. W ostatniej części zaprezentowano socjologię ludzkiej aktywności fizycznej powiązanej ze sportem i turystyką. J. Szymczyk analizował w swojej socjologii strukturę i polimorficzność sportu, ale także przede wszystkim podstawowe wartości aktywności sportowej: ekonomiczne, biologiczno-witalne, etyczne, estetyczne i polityczne. Występował także przeciw dewiacjom w sporcie wyczynowym zorientowanym na bicie rekordów. Współcześnie sport jest często powiązany z posiadającymi wiele wartości turystyką i odpoczynkiem.

Słowa kluczowe: socjologia ciała, fizyczna aktywność, sport, turystyka

\section{Jan Szymczyk's Sociology of Body and Physical Culture}

\section{Summary}

The paper has three parts. The first part discusses humanistic-axiological profile of Szymczyk's sociology. According to this researcher, values are strongly connected with the human person: elementary values bring sense to human life and create bonum commune of society; therefore, moral relativism is destructive for culture and social order. The second part of the article treats about the meaning of the human body; its consequence for individual and social life; and socio-cultural as well as economic transformations of the concept of the body. The final part of the paper presents the sociology of man's physical activity connected with sport and tourism. In his sociological works, Szymczyk analyses the structure and the polymorphism of sport, but mainly focuses on the principial values of sport's activity: economic, biological-vital, ethical, aesthetic and political. He also warns against the deviated tendency for professional record-seeking in contemporary sport. The present-day sport is often connected with tourism active and passive, which has many values.

Key words: sociology of body, physical activity, sport, tourism 